Article

\title{
Wild Boar Meat as a Sustainable Substitute for Pork: A Mixed Methods Approach
}

\author{
Karolina Macháčková ${ }^{1}\left[\right.$, Jiř́ Zelený ${ }^{2, *}$, , Daniel Lang $^{3}$ and Zbyněk Vinš ${ }^{2}$ \\ 1 Department of Forestry and Wood Economics, Faculty of Forestry and Wood Sciences, \\ Czech University of Life Sciences Prague, 16500 Prague, Czech Republic; machackovak@fld.czu.cz \\ 2 Department of Hotel Management, Institute of Hospitality Management, 18200 Prague, Czech Republic; \\ vins@vsh.cz \\ 3 Department of Languages, Institute of Hospitality Management, 18200 Prague, Czech Republic; lang@vsh.cz \\ * Correspondence: zeleny@vsh.cz; Tel.: +420-731-418-898
}

check for updates

Citation: Macháčková, K.; Zelený, J.; Lang, D.; Vinš, Z. Wild Boar Meat as a Sustainable Substitute for Pork: A Mixed Methods Approach. Sustainability 2021, 13, 2490. https://doi.org/10.3390/su13052490

Academic Editor: Flavio Boccia

Received: 30 January 2021

Accepted: 19 February 2021

Published: 25 February 2021

Publisher's Note: MDPI stays neutral with regard to jurisdictional claims in published maps and institutional affiliations.

Copyright: (C) 2021 by the authors. Licensee MDPI, Basel, Switzerland. This article is an open access article distributed under the terms and conditions of the Creative Commons Attribution (CC BY) license (https:// creativecommons.org/licenses/by/ $4.0 /)$.

\begin{abstract}
Sensory analysis is unusual in sustainability research, although it can offer a neoteric aspect of nature and wild animals' perception. The study's objective was to identify consumers' attitudes towards plant and animal products from wild and conventional foods and put these findings into a broader social context. A blind sensory evaluation with 80 semi-trained assessors was used, segmented by gender, age, education, income, place of origin, family status, number of children, and willingness to pay. Wild boar (Sus scrofa) was chosen as an example of an overpopulated animal species occurring in the wild, which could be considered a partial substitute for pork. Statistical testing in these blind evaluations proved that wild boar meat is not considered less tasty. Therefore, wild boar meat could represent a partial substitute, complementing pork, on which consumers are willing to spend the same amount of money. Despite the mostly indifferent sensory evaluation, focus group responses showed considerable barriers to wild food. This paper concludes that possible educational and popularizing procedures are presented, including forest pedagogy, eliminating consumers' prejudices. A mixed-methods approach within quantitative and qualitative methodology was chosen.
\end{abstract}

Keywords: consumer panel; focus groups; forest pedagogy; sensory evaluation; nutritional properties; willingness to pay

\section{Introduction}

Considerable natural and material resources are spent on meat production, which has consequences for the environment [1,2]. On the other hand, there are overpopulated species living in the wild, which could be a partial substitute for pork, beef, or poultry produced from factory farms; nevertheless, the consumption rate is low [3-5]. Humans and livestock together represent $97 \%$ of the bodyweight of all living terrestrial vertebrates on Earth [6]. The EAT-Lancet report (2019) quantified the recommended meat consumption at less than 28 grams of beef, lamb, or pork per day [7]. Despite this recommendation, according to the Food and Agriculture Organization (FAO 2015), global meat production in 2025 is expected to be 16\% higher than in the base period (2013-15) [8].

Meat may come from slaughter animals or animals living in the wild. The current system of raising animals for food requires enormous amounts of land, water, and energy [1,2]. In 2006, the United Nations estimated that livestock production was responsible for $18 \%$ of carbon dioxide, methane, and nitrous oxide [9]. The calculation for total overall greenhouse gas emissions from pork production and consumption is $12.1 \mathrm{~kg} \mathrm{CO}$ per $1 \mathrm{~kg}$ and includes processing, domestic transport, retail refrigeration home cooking, and waste disposal; for comparison, the greenhouse gas emissions produced by $1 \mathrm{~kg}$ of lamb and beef are $39.2 \mathrm{CO}_{2}$ and $27.0 \mathrm{CO}_{2}$, respectively [10]. 
Sus scrofa is the organic foodstuff of local wildlife origin (no breeding, heating, storage of excrement, feeding, feed production). Wild boar comes from living in the wild, is freerange and is not intentionally produced. Unlike meat from large farms, wild boars have not been selectively bred over centuries. So, they do not suffer from many of the diseases that traditional farm animals do (transmissible gastroenteritis, circovirosis, vesicular rash, Aujezky's disease, Swine erysipelas), nor are they given antibiotics, or hormones [11]. For these reasons, wild boar meat has a negligible carbon footprint compared to meat produced from industrialized farming, being a natural product. Accurate data of greenhouse gas emissions produced by $1 \mathrm{~kg}$ wild boar meat are not available; methodology of exact detection and measurement could be an independent research topic.

The hunting statistics of selected European Union countries for the period 2012-2019 (as of 31 March 2020) reveal that in many areas of Europe, the red deer (Cervus elaphus) is overpopulated, in others the Japanese sika (Cervus nippon) or the fallow deer (Dama dama). Biological invaders generally exhibit three primary characteristics: rapid spread into unexplored areas, competitive advantage over existing species, and a dominant population [12]. One such invader meeting all criteria is the invasive wild boar Sus scrofa that has been introduced to all continents except Antarctica, and currently is one of the most widely distributed mammals [13-15]. In recent decades, the wild boar Sus scrofa has simultaneously increased its population size and colonized new habitats, causing more concern than perhaps any other ungulate species $[15,16]$. Currently, Sus scrofa is overpopulated in European countries such as Austria, Belgium, Croatia, Poland, Denmark, Estonia, Finland, France, Germany, and the Czech Republic [17-21]. Invasive wild boars are also expanding across large regions of the USA and appear to be gaining momentum [22-24]. Sus scrofa expansion's success can be attributed mainly to their adaptable biology and feeding behavior [25-27]. To curtail the invasion of wild boars, several authors $[17,23,24,27,28]$ introduced models to predict the future spread of wild boars. Spread into more regions could significantly increase the consequences associated with damage to agriculture and natural resources. The number of wild boars significantly affects small game species such as brown hare, pheasant, rabbit, grey partridge [29]. Wild boar numbers in Europe are now at a level that requires a solution that most often involves culling and hunting, which can be considered a sustainable management tool for controlling wildlife populations [30-32]. Appropriate hunting practices may reduce the impact wild animals have on agriculture [33]. As shown by Turek et al. [29], wild boar numbers have a growing tendency, based on the ratio of blasts to hectares. Between 55 and $70 \%$ of a wild boar population should be blasted each year to suppress population growth [34]. Based on the above, the game thus becomes one of the most affordable and sustainable sources of meat ever [35]. Meat from wild animals that was gained by an authorized hunting method is defined as game meat. At present, 97 species of animals are allowed to be hunted in the European Union, but only a part is consumed, namely 12 species of mammals and 26 species of birds [21,36,37]. Despite these options, consumers still negatively affect hunters and hunting practices [38-40].

\subsection{Consumers' Preferences on Various Types of Meat}

Universal trends in game meat consumer attitudes include convenience foods, safety and quality issues [41]. Studies confirm that it is the content of cholesterol and saturated fats in red meat that are the most influential factors in consumer choice [42-44]. Consumers also require eating experience and the knowledge that the animal had a free life or was harvested scientifically. Due to the livestock diseases (such as swine fever virus, avian influenza), attributes such as origin, traceability, and processing practices have become consumers' prime concerns when purchasing meat products [43,44]. Bureš [3] conducted a survey focused on the frequency and popularity of individual types of meat among consumers, revealing that chicken meat is the most frequent meat consumed by $49 \%$ of respondents within the questionnaire survey, which was presented to 210 consumers. The questionnaire consisted of questions focused on the popularity and frequency of meat 
consumption. Game meat was assessed by $5 \%$ of respondents as the most popular type of meat, and $6 \%$ described it as the most frequently consumed meat.

Regarding the frequency of game meat consumption, $21 \%$ of respondents stated that they do not consume this type of meat at all, and a quarter of consumers $(25 \%)$ only 1-2 times a year. Most respondents (29\%) reported the frequency of consumption 2-4 times a year, while only $9 \%$ reported more frequent consumption than once a month. These findings confirm the significant differences in the popularity and consumption of this specific type of meat. The frequency of consumption can be greatly limited by meat availability in the regular market network. One-quarter of the survey participants (25\%) mentioned wild boar meat as the most popular type. In addition to the specific organoleptic properties, this fact could again be related to the highest availability of wild boar meat, representing $60 \%$ of game meat production in the Czech Republic [45]. The second place is taken by venison meat $(17 \%)$ and the third place by hare meat $(16 \%)$.

Differences in the frequency of consumption of the game meat can be observed between men and women. At least once a month, $24 \%$ of men consume game meat, while only $14 \%$ of women do so [3]. Comparable results were found in the analysis of Western European countries' eating habits, specifically that men consume approximately 40 to 50\% more meat in general in their daily diet than women [46]. Its affordability also explained the reasons for consuming chicken meat, examining the relationship between income and purchased meat product; disposable income is of the utmost importance when consumers make purchasing decisions [47]. Consumer preferences are determined by social norms, habits, price and marketing activities [48]. The majority of consumers buy their meat in supermarkets because they assume that the meat will be fresh and cheap $[47,49,50]$.

It follows that game meat is not a standard part of most of the population's diet. Traditionally, the highest consumption is in hunter families, while most domestic populations do not consume game meat at all [3]. The average consumption per person per year in France, Germany, Austria, Switzerland, and the United Kingdom is lower than $2 \mathrm{~kg}$ of game meat per capita [3,32]. Sweden is a notable exception to this, with a significantly higher rate of annual consumption. Reasons for limited game meat consumption include changing dietary trends and the transition to vegetarianism or veganism, the taste of game meat, ethical reasons, fears of disease, and unfamiliarity or nescience of appropriate culinary preparation [51].

Another critical attribute that consumer consider when making food choices is animal welfare [52-59]. Meat from the wild game can have the highest level of animal welfare amongst meat products if harvested under strict and regulated hunting practices, thereby eliminating the process of transport and slaughter that cause stress and pain to livestock husbandry [41,60-63]. Positive attitude towards game meat, including animal welfare, affects the willingness to pay (WTP) [38]. WTP can be understood as the maximum price at which a consumer is willing to buy one unit of a product $[62,63]$. Pro-consumer behavior and WTP depends on how consumers perceive meat safety, animal welfare, and hunting activities. These general attitudes affect consumer intentions to purchase game meat products $[40,64,65]$.

\subsection{Nutritional Values of Wild Boar Meat and Pork and Their Sensory Evaluation}

In terms of nutritional value and organoleptic properties, game meat meets the demanding expectations of current consumers [66], and therefore, game meat can represent a partial substitute for traditional livestock meat. According to Ježek [67], game meat generally represents a precious renewable natural resource, even nutritional value and specific sensory properties. Nutritional value of foodstuff expresses data on the number of substances contained, such as proteins, fats, carbohydrates, vitamins, minerals and trace elements, fiber, carotenoids [68]. The game meat's main advantage is its low-fat content; therefore, it is also appropriate for low-fat dietetic cuisine $[61,69]$. The game's meat energy value is about $90-110 \mathrm{kcal} / 100 \mathrm{~g}$ lower than animals for slaughter [70]. The game meat 
contains $72-77 \%$ of water [71]. The average nutritional values for pork and wild boar meat are given in Table 1.

Table 1. Content and nutritional values of wild boar and pork meat.

\begin{tabular}{cccccccc}
\hline & Energy & Proteins & Carbohydrates & Fats & \multicolumn{2}{c}{ Cholesterol } & Water Content \\
\hline $100 \mathrm{~g}$ & $(\mathrm{kcal})$ & $(\mathrm{g})$ & $(\mathrm{g})$ & $(\mathrm{g})$ & $(\mathrm{mg})$ & $(\mathrm{g})$ & 71.1 \\
\hline Mean values for pork meat & 182 & 18.6 & 0 & 23.9 & 101.0 & 75.0 & 75.1 \\
\hline Mean values for wild boar meat & 110 & 22.2 & 0 & 4.0 & 45.0 & \\
\hline
\end{tabular}

Protein values in the game meat range from 17 to $26 \%$ depending on wild animals and meat types. These complete proteins contain all essential amino acids such as isoleucine, leucine, lysine, methionine, cystine, phenylalanine, tyrosine, threonine, tryptophan, and valine. The highest proportion of essential amino acids is found in wild boars' muscle, precisely $7.99 \mathrm{~g} / 100 \mathrm{~g}$ [73].

If we compare the content of vitamins in the meat of domestic pig (Sus scrofa domesticus) and wild boar (Sus scrofa) in $\mathrm{mg} / 100 \mathrm{~g}$, Sus scrofa has less thiamine (0.355) in its meat compared to the domestic pig (0.416), but more riboflavin (0.168) and vitamin B (0.602) [71]. Minerals represent $1 \%$ of all substances in pork (Sus scrofa domesticus); however, this meat is a rich source of B vitamins [22]. A technologically important pork quality feature is the final $\mathrm{pH}$ value, which affects the ability to bind water and the meat's colour [74,75].

Wild boar meat is characterised by lower tenderness than meat from the Yorkshire species [76]. This may be caused by the length of the muscle fiber sarcomere [77]. Due to the endo- or perimysium thickness, a ligament is located on the muscle's surface and forms partitions towards the muscle [78]. Shorter sarcomere lengths in wild boars may affect the textural properties of meat [77].

\section{Sensoric Evaluation of Pork and Game Meat}

Sensory analysis is unusual in sustainability research, and therefore, it can offer a new perspective on the problematics researched by involving sensory perceptions by bringing a neoteric aspect of the perception of nature and wild animals. Consequently, researchers focused on the taste senses in this research.

Sensory analysis is a complex assessment including an evaluation of appearance, aroma (orthonasal and retronasal), taste, juiciness, and textural properties [79,80]. The monitored sensory evaluation parameters include aroma, meat color, flavor (The term flavour is defined in sensory analysis according to ISO 5492 as the overall combination of olfactory, taste and trigeminal perception perceived during testing), taste, tenderness, juiciness, and appearance. Trained assessors and consumers assess selected sensory parameters during the so-called consumer tests. According to ISO 6658: 2017 [81], which was also used in our research, scales expressing quality, intensity or pleasantness are most often used for sensory evaluation. These hedonic scales are always arranged in a specific sequence. The hedonic scale is used to assess the degree of pleasantness, acceptability and pleasure. Hedonic testing is widespread in sensory analysis and irreplaceable by using another instrumental method [82,83].

Rødbotten [84] proposed to divide sensory parameters into four groups, namely evaluation of odor, color on fresh-cut, flavor and texture. The game's meat color is dark, red to brownish, and its taste is species-specific [85]. Other authors have submitted their rating scales, as shown in Table 2. This research uses the traditional hedonic scale according to Peryam and Pilgrim [86], a 9-point scale from Dislike Extremely (1) to Like Extremely (9). The word anchors of the scale were chosen so that the scale's following points' psychological distance was approximately the same. This property of the same interval helps justify the response analysis procedure by assigning whole successive values (1-9) to the scale points and testing acceptability differences. 
Table 2. The hedonic scale of taste, aroma, odor and juiciness.

\begin{tabular}{|c|c|c|c|c|}
\hline & [87] & [87] & [88] & [89] \\
\hline & Hedonic Scale & Hedonic Scale & Hedonic Scale & Hedonic Scale \\
\hline & Taste Evaluation & Aroma Evaluation & Odor Evaluation & Juiciness Evaluation \\
\hline 1 & very unpleasant & imperceptible & very bad & the driest \\
\hline 2 & slightly unpleasant & perceptible & bad &.. \\
\hline 3 & indistinct & slightly distinctive & acceptable & .. \\
\hline 4 & pleasant & distinctive & satisfactory & .. \\
\hline 5 & very pleasant & very distinctive & excellent & juicy \\
\hline
\end{tabular}

For wild boar meat, tenderness, juiciness, color, taste, aroma, and off-flavors are significantly correlated with the general quality of meat, assessed by the sensory panel. Guzek's study [90] indicates that wild boar meat shows characteristic sensory traits; however, texture and off-flavors do not play an essential role in creating general quality. This observation is essential, as, in the case of meat from domestic livestock, tenderness is one of the most critical quality attributes for consumers [91]. The sensory evaluation results also differ according to whether the pigs were vaccinated against gonadotropin or surgically castrated [92]. Adam et al. [93] assessed the quality and sensory evaluation of meat from Nilotic goat kids fed on two different diets. The consumer panel comprised of 12 semiexpert assessors considered leanness above all other attributes of meat quality. Nilotic goat kids have lower fat content than other goat breeds. Vigano et al. [94] carried out sensory analysis and $\mathrm{pH}$ monitoring of chamois, roe deer, red deer, and wild boar without assessors' consumer testing. Wild game meat has high values of $\omega 3$ and CLA, ensuring a positive $\omega 6 / \omega 3$ ratio. Differences were found in the concentrations of fat between age and gender.

Meat quality is significantly affected by hunting practices. Bureš et al. [95] compared the physical characteristics, chemical composition and sensory attributes of meat obtained from red deer, fallow deer, Aberdeen Angus and Holstein cattle raised under conditions typical for commercial farming practice and slaughtered at similar ages. Steaks prepared from venison scored higher than beef for flavor and aroma intensity; they were also tenderer and more easily chewable. Samples were presented to a sensory panel composed of 10 trained assessors. Marchiori and Felício [96] compared the quality of wild boar meat to commercial pork, focused on postmortem changes in the longissimus dorsi and semimembranosus muscles were determined by $\mathrm{pH}$, temperature decline and color measurements. They concluded that wild boar meat has advantages over pork, manifested by a more intense red coloration and, in particular, in females, by a smaller exudate loss in the drip loss test. These differences can be explained by the behavior and feeding of wild boars in nature. This research also took place without consumer testing of evaluators. Miao et al. [97] compared calcium, copper, iron, and zinc concentrations in pork and wild boar meat. The results showed that calcium concentrations of gluteus in boar meat and pork were not significantly different, zinc, iron, cope concentrations of gluteus in wild boar meat were higher than those of pork. Kasprzyk et al. [77] assessed meat quality and ultrastructure of muscle tissue from three genetic groups of pork and wild boar meat. Lower diameters were characteristic for wild boars. The shortest sarcomeres were established in a group of wild boars $(2.03 \mu \mathrm{m}$ MLD and $2.31 \mu \mathrm{m}$ MS) which may confirm the association with their meat tenderness.

Variances in the dish's sensory properties can be achieved through substitutions, replacing at least one of the raw materials and changing the food preparation method. In the case of meat dishes, both forms of these substitutions have been investigated. The effect of changes during preparation of the final meal using the same meat was investigated, for example, by Górska et al. [98]. The substitution of raw materials has been extensively studied in previous studies, and the substitution methods can be divided into several types. 
One of them is the exchange of individual meat cuts to prepare the same type of dish. Another possibility is the substitution of an animal of the same breed, which was bred differently. The study of Chumngoen and Tan [99] examined the sensory characteristics of meat when comparing commercial broiler and Taiwan native chicken, focused on substituting meat of one breed for the meat of another breed and the same species. The last option is to replace with the meat of a more or less related species, see, e.g., more general studies $[100,101]$ trying to point out the possibility of substituting completely different species in meals-sheep and goat for pork, beef and poultry, and extreme substitution of meat as a raw material for plant-based ingredients [102,103].

\section{Materials and Methods}

Due to the issue's scope, one objective was chosen, and two research methods were determined. In the research survey, the mixed-methods approach of qualitative and quantitative research methodology was used.

The study's objective is to identify sensory assessors' preferences towards wild food focusing on wild boar meat and put these findings into a broader social context. A mixedmethods approach within quantitative and qualitative methodology was chosen to meet the objective as stated below.

Method 1: Sensory evaluation by semi-trained assessors;

Method 2: Focus groups with semi-trained assessors following after the sensory evaluation.

\subsection{Sensory Evaluation of Pork and Wild Boar Meat by Semi-Trained Assessors}

Sensory evaluation within this research was carried out with eighty $(n=80)$ semitrained assessors, whose fundamental socio-demographic indicators are given in Table 3.

Table 3. Fundamental socio-demographic indicators of semi-trained assessors.

\begin{tabular}{|c|c|c|}
\hline Socio-Demographic Characteristics & Values & $\%$ Representation \\
\hline \multirow{2}{*}{ Gender } & Male & 46.25 \\
\hline & Female & 53.75 \\
\hline \multirow{2}{*}{ Education } & Secondary (including school-leaving certificate) & 43.75 \\
\hline & Higher (all levels) & 56.25 \\
\hline \multirow{3}{*}{ Age ${ }^{1}$} & Generation $\mathrm{Y}$ (younger segment) $16-24$ years & 50.00 \\
\hline & Generation Y (older segment) 25-32 years & 20.00 \\
\hline & Non-millennials 33+ & 30.00 \\
\hline \multirow{3}{*}{ Income $^{2}$} & Below average in $\mathrm{CZ}$ & 42.50 \\
\hline & Average in $\mathrm{CZ}$ & 26.25 \\
\hline & Above average in $\mathrm{CZ}$ & 18.75 \\
\hline \multirow{2}{*}{ Place of origin } & Rural & 26.25 \\
\hline & Urban & 73.75 \\
\hline \multirow{2}{*}{ Family situation } & Live with a partner & 57.50 \\
\hline & Live alone & 42.50 \\
\hline \multirow{2}{*}{ Household with children } & One or more children in the household & 28.75 \\
\hline & No children or no child/children sharing a household & 71.25 \\
\hline
\end{tabular}

Own elaboration, 2020. Note: ${ }^{1}$ the division, according to [104] was used to differentiate generation segments; ${ }^{2}$ income statements do not give a $100 \%$ total because not all assessors answered this question. 
The number of assessors can be considered sufficient based on the often-used central limit theorem for sensory evaluation. As the research was conducted in 2019, the cut-off point for Millennials and non-Millennials is being born in 1986 and 1987. The younger generation Y segment's upper year of birth was 2001. Although more possibilities of generation categorization are possible, we decided to use segmentation previously used in sensory evaluation, e.g., by Zelený and Bednárová [104]. The sensory testing's objective was to identify consumers' attitudes regarding plant and animal products from the wild (wild foods-wild boar meat, cranberries, and wild mushrooms) and conventional foods (garden champignons, red currant, and pork meat). Thus, there were also dishes used in the sensory evaluation for which the substitution of pork with wild boar meat was not tested, but the substitution of other conventional raw ingredients with wild foods was possible, which makes it possible to place the obtained results in a broader context. The following dishes were made from Classic (C) and Wild foods (W) ingredients, namely, starters (1), main courses (2), and desserts (3), as can be seen in Table 4.

Table 4. Ingredients and procedure of preparation of individual courses.

\begin{tabular}{|c|c|c|c|}
\hline Dish Code and Dish Name & $\begin{array}{l}\text { Ingredients Identical for } \\
\text { Both Dishes }\end{array}$ & $\begin{array}{l}\text { Ingredients Differentiating } \\
\text { the Pair of Dishes }\end{array}$ & Preparation Process \\
\hline Champignon pâté (C1) & \multirow[b]{2}{*}{$\begin{array}{l}\text { Butter, onion, garlic, white } \\
\text { wine, salt, pepper, thyme, } \\
\text { walnuts }\end{array}$} & Champignons & \multirow{2}{*}{$\begin{array}{l}\text { Roast the nuts dry. Glaze } \\
\text { onion, mushrooms, garlic in } \\
\text { butter, cover with wine and let } \\
\text { evaporate. Add spices, } \\
\text { roasted nuts and simmer } \\
\text { until soft. }\end{array}$} \\
\hline Wild mushroom pâté (W1) & & Wild mushrooms & \\
\hline Pork goulash (C2) & \multirow[b]{2}{*}{$\begin{array}{l}\text { Black pepper, juniper, cumin, } \\
\text { allspice, bay leaf, onion, butter, } \\
\text { bacon, red wine, plain flour }\end{array}$} & Pork leg, pork broth & \multirow{2}{*}{$\begin{array}{l}\text { Cook the broth from the } \\
\text { spices and bones, into which } \\
\text { the meat is loaded for } 24 \mathrm{~h} \text {. } \\
\text { Fry onion and cumin in butter, } \\
\text { add meat, bacon, broth, cover } \\
\text { with wine and stew until soft. }\end{array}$} \\
\hline Wild boar goulash (W2) & & Wild boar leg, wild boar broth & \\
\hline Dessert with red currants (C3) & \multirow[b]{2}{*}{$\begin{array}{l}\text { Slices of toast, cream, sugar, } \\
\text { eggs, breadcrumbs, butter }\end{array}$} & Currant jam & \multirow{2}{*}{$\begin{array}{l}\text { Moisten the toast with cream } \\
\text { with sugar, spread with jam, } \\
\text { and press together. Wrap in } \\
\text { egg and breadcrumbs and fry } \\
\text { in butter. }\end{array}$} \\
\hline $\begin{array}{l}\text { Dessert with wild cranberries } \\
\text { (W3) }\end{array}$ & & Cranberry jam & \\
\hline
\end{tabular}

Own elaboration, 2020.

In addition to the above-mentioned standard ISO 6658: 2017 (2017) [81], ISO standards 8589,6658 , and 5568 were also used in the sensory evaluation $[105,106]$. The evaluators were asked to determine how much CZK they would be willing to pay for the restaurant's meal, separately for appetizers, desserts, and main courses. The price difference for starters and desserts was 10 CZK, for the main course 15 CZK (The average USD/CZK exchange rate in 2019-1 USD = 22,934 CZK according to the Czech National Bank [107]). Due to the use of the ordinal scale, a non-parametric statistical test was used, the Wilcoxon paired test, allowing to compare interdependent samples; in the case of our research, differences in evaluation for the tested pair dishes were always concerned. Subsequently, the results of the sensory evaluation were grouped depending on the socio-demographic characteristics of the assessors. Specifically, the results were grouped by gender, age group, education, place of origin (urban or rural), income, and family situation. Within each of the groups created, the above statistical test was performed for all three pairs of dishes. However, in the results section, only those results are presented in which, depending on the sociodemographic characteristics, statistically significant differences occurred. All statistical tests were carried out at significance level $\alpha=5 \%$. 


\subsection{Qualitative Research Survey Using Focus Groups}

Focus groups were conducted with all sensory evaluation participants to explain the assessors' preferences for wild foods and present them in a broader social context. Each focus group took place with 10 participants; thus, eight focus groups were held. The method allowed the agent-assessors to interact with each other [108] and the researcher's agentassessors. Focus groups enabled good group dynamics [109], allowing for an in-depth discussion of assessors' specific evaluation, first before declassifying the tasted dishes and subsequently after declassifying the tasted dishes. The research topics also included more general attitudes towards wild-food consumption, independently from sensory evaluation. Each of the participants in the sensory evaluation could refuse to participate in the focus group in advance. Likewise, participants were not forced to answer during focus groups if they did not wish to speak. There was an effort to ensure that only one participant in the group spoke to take turns while explaining their statements. Likewise, all participants were allowed to comment on the issue if they were interested. For critical statements, transcription was performed (including substandard expressions), followed by an analysis of the obtained data, coding of the same thematic units and subsequent integration of the units to a higher level up to the final synthesis.

\section{Results}

The results are divided according to the mentioned methodology, sensory evaluation and related focus groups.

\subsection{The Results of Sensory Evaluation of Pork and Wild Boar Meat by Semi-Trained Assessors}

The sensory evaluation results without grouping of assessors (i.e., in summary for all assessors) are shown in Table 5.

Table 5. Sensory evaluation of acceptability and willingness to pay (WTP) without grouping of assessors.

\begin{tabular}{|c|c|c|c|c|}
\hline \multirow{2}{*}{ Evaluated Dish } & \multicolumn{2}{|c|}{ Sensory Evaluation of Acceptability } & \multicolumn{2}{|c|}{ WTP in CZK } \\
\hline & Total for All Assessors ${ }^{1}$ & $p$-Value ${ }^{2}$ & Total for All Assessors ${ }^{1}$ & $p$-Value ${ }^{2}$ \\
\hline Champignon pâté (C1) & $5.68 \pm 2.27$ & \multirow{2}{*}{$0.03 *$} & $54.68 \pm 16.55$ & \multirow{2}{*}{$0.00 *$} \\
\hline Wild mushroom pâté (W1) & $5.27 \pm 2.15$ & & $51.27 \pm 16.28$ & \\
\hline Pork goulash (C2) & $6.42 \pm 1.88$ & \multirow[b]{2}{*}{0.53} & $152.03 \pm 29.30$ & \multirow[b]{2}{*}{0.43} \\
\hline Wild boar goulash (W2) & $6.59 \pm 1.80$ & & $153.94 \pm 28.87$ & \\
\hline Red currant dessert (C3) & $6.75 \pm 1.71$ & \multirow[b]{2}{*}{$0.00 *$} & $69.11 \pm 20.89$ & \multirow[b]{2}{*}{$0.00 *$} \\
\hline Cranberry dessert (W3) & $6.19 \pm 1.96$ & & $64.43 \pm 21.11$ & \\
\hline
\end{tabular}

Note: ${ }^{1}$ Results correspond to mean values \pm standard deviation; ${ }^{2}$ Wilcoxon test, where ${ }^{*}$ indicates a statistically significant difference between groups $(\alpha=5 \%)$.

It is apparent that if a statistically significant difference in the evaluation between a pair of dishes occurs, this difference is also evident in WTP in CZK for the same pair of dishes. In this case, the dish's more significant popularity among assessors was always reflected in their willingness to spend their money on this kind of dish. Overall, the assessors preferred champignons to wild mushrooms for starters $(p=0.03)$ and were also willing to pay more for such dishes containing champignons $(p<0.01)$. The same situation occurred with desserts, where they preferred red currants over wild cranberries $(p<0.01)$ and were willing to pay more for red currants in the dessert $(p<0.01)$. Thus, wild foods do not appear to be a suitable substitute for conventional foods in the dishes mentioned above. Nevertheless, as far as the main courses were concerned, the assessors generally perceived wild boar and pork meat as interchangeable substitutes-the taste of the dish for them was without a difference $(p=0.53)$, which was reflected in the willingness to pay approximately the same amount of money $(p=0.43)$. From this point of view, we can deduce an outstanding potential for the use of wild boar meat in gastronomy, if it substitutes pork, significantly more than in other wild foods. 
Statistically significant differences in the evaluation depending on their grouping according to socio-demographic characteristics were found for gender, place of origin (urban or rural), and generational segments, whereas no multicollinearity was found for these variables. Multicollinearity was found, for example, in younger assessors, who were more often students. Only results that include these statistically significant differences are presented below. On the contrary, the evaluation results depending on the grouping according to education, income and family situation, where no statistically significant differences were found, are not presented.

When looking at gender grouping, different preferences appeared only in men, not in women, as shown in Table 6. Men were more willing to pay extra $(p=0.02)$ and preferred $(p=0.02)$ starters prepared from champignons rather than wild mushrooms. They also preferred $(p<0.01)$ and were more willing to pay extra $(p<0.01)$ for desserts containing red currants rather than wild cranberries. However, even in more demanding males, it was possible to consider boar meat as a full substitute for pork meat ( $p=0.57$ and $p=0.32$ ). In contrast, women were less demanding overall and did not differentiate in preferences between wild foods and conventional foods ingredients-indifferent attitudes were present in all dishes examined, both in sensory preferences and in WTP (for all from $p=0.08$ to $p=0.85$ ).

Table 6. Sensory evaluation of acceptability and WTP in the grouping of assessors depending on gender.

\begin{tabular}{|c|c|c|c|c|c|c|c|c|}
\hline \multirow{2}{*}{ Eval. Dish } & \multicolumn{4}{|c|}{ Sensory Evaluation of Acceptability } & \multicolumn{4}{|c|}{ WTP in CZK } \\
\hline & Males $^{1}$ & $p$-Value & Females $^{1}$ & $p$-Value & Males $^{1}$ & $p$-Value & Females $^{1}$ & $p$-Value ${ }^{2}$ \\
\hline $\mathrm{C} 1$ & $6.36 \pm 1.72$ & \multirow{2}{*}{$0.02 *$} & $5.12 \pm 2.53$ & \multirow{2}{*}{0.47} & $58.33 \pm 17.97$ & \multirow{2}{*}{$0.02 *$} & $51.63 \pm 14.79$ & \multirow{2}{*}{0.33} \\
\hline W1 & $5.50 \pm 1.84$ & & $5.07 \pm 2.37$ & & $52.22 \pm 17.58$ & & $50.47 \pm 15.27$ & \\
\hline $\mathrm{C} 2$ & $6.83 \pm 1.16$ & \multirow{2}{*}{0.57} & $6.07 \pm 2.28$ & \multirow[b]{2}{*}{0.59} & $151.25 \pm 24.94$ & \multirow[b]{2}{*}{0.32} & $152.67 \pm 32.79$ & \multirow[b]{2}{*}{0.85} \\
\hline W2 & $6.86 \pm 1.36$ & & $6.37 \pm 2.09$ & & $154.58 \pm 30.03$ & & $153.37 \pm 28.22$ & \\
\hline $\mathrm{C} 3$ & $6.64 \pm 1.50$ & \multirow{2}{*}{$0.00 *$} & $6.84 \pm 1.89$ & \multirow{2}{*}{0.08} & $66.94 \pm 17.70$ & \multirow{2}{*}{$0.00 *$} & $70.93 \pm 23.28$ & \multirow{2}{*}{0.08} \\
\hline W3 & $5.83 \pm 2.02$ & & $6.49 \pm 1.88$ & & $61.11 \pm 18.94$ & & $67.21 \pm 22.61$ & \\
\hline
\end{tabular}

Note: ${ }^{1}$ Results correspond to mean values \pm standard deviation; ${ }^{2}$ Wilcoxon test, where * indicates a statistically significant difference between groups $(\alpha=5 \%)$.

When examining the grouping by place of origin, the urban environment assessors were more selective than the rural environment's assessors, as shown in Table 7. Urban assessors - the same as males—statistically significantly had a greater preference for starters with champignons $(p=0.03)$, for which they were willing to pay more $(p=0.03)$ than dishes with wild mushrooms. Even for desserts, urban assessors preferred more the content of red currants than wild cranberries $(p<0.01)$ with a higher WTP for such a dish $(p<0.01)$. There was no difference in preferences and WTP between urban and rural assessors (for all from $p=0.12$ to $p=0.97$ ). Thus, it can be stated that for the dishes examined, two groups were formed in the preferences and WTP. The first group, more demanding, in which a group of males and a group of urban assessors overlapped in preferences and WTP. In the second, less demanding, a group of females overlapped with a group of rural assessors. In the second group, all wild ingredients examined can substitute conventional ingredients. Rural assessors preferred wild cranberries significantly more to red currants $(p<0.01)$. However, even for the more demanding group, it was possible to consider wild boar meat as a suitable substitute for pork. 
Table 7. Results of sensory evaluation of acceptability and WTP in the grouping of assessors depending on the place of origin.

\begin{tabular}{|c|c|c|c|c|c|c|c|c|}
\hline \multirow{2}{*}{$\begin{array}{c}\text { Eval. } \\
\text { DISH }^{1}\end{array}$} & \multicolumn{4}{|c|}{ Sensory Evaluation of Acceptability } & \multicolumn{4}{|c|}{ WTP in CZK } \\
\hline & Urban & $p$-Value ${ }^{2}$ & Rural & $p$-Value ${ }^{2}$ & Urban & $p$-Value ${ }^{2}$ & Rural & $p$-Value $^{2}$ \\
\hline $\mathrm{C} 1$ & $6.28 \pm 1.85$ & \multirow[b]{2}{*}{$0.03 *$} & $5.92 \pm 2.27$ & \multirow[b]{2}{*}{0.49} & $58.33 \pm 17.97$ & \multirow[b]{2}{*}{$0.03 *$} & $51.63 \pm 14.79$ & \multirow[b]{2}{*}{0.27} \\
\hline W1 & $5.95 \pm 1.61$ & & $6.19 \pm 1.91$ & & $52.22 \pm 17.58$ & & $50.47 \pm 15.27$ & \\
\hline $\mathrm{C} 2$ & $6.66 \pm 1.72$ & \multirow[b]{2}{*}{0.34} & $6.43 \pm 2.04$ & \multirow[b]{2}{*}{0.97} & $151.25 \pm 24.94$ & \multirow[b]{2}{*}{0.12} & $152.67 \pm 32.79$ & \multirow[b]{2}{*}{0.41} \\
\hline W2 & $6.43 \pm 1.86$ & & $6.38 \pm 1.99$ & & $154.58 \pm 30.03$ & & $153.37 \pm 28.22$ & \\
\hline $\mathrm{C} 3$ & $6.41 \pm 2.03$ & \multirow{2}{*}{$0.00 *$} & $4.86 \pm 2.46$ & \multirow{2}{*}{$0.00^{*}$} & $66.94 \pm 17.70$ & \multirow{2}{*}{$0.00 *$} & $70.93 \pm 23.28$ & \multirow{2}{*}{0.44} \\
\hline W3 & $5.90 \pm 2.25$ & & $5.10 \pm 2.28$ & & $61.11 \pm 18.94$ & & $67.21 \pm 22.61$ & \\
\hline
\end{tabular}

Note: ${ }^{1}$ Results correspond to mean values \pm standard deviation; ${ }^{2}$ Wilcoxon test, where * indicates a statistically significant difference between groups $(\alpha=5 \%)$.

The last grouping by generation segment showed statistically significant differences across generations and dishes, as shown in Table 8. No generation segment showed a difference in the evaluation of starters in terms of the content of wild mushrooms or champignons. Therefore, age was not a decisive factor (from $p=0.14$ to $p=0.82$ ). However, in the youngest segment, an exception to the consistent results appeared, precisely the willingness to pay significantly more for a dish prepared from champignons rather than wild mushrooms $(p<0.01)$, despite equal popularity of both ingredients. In the tested pair of desserts, the youngest generation did not make any difference in preferences or WTP $(p=0.14$ and $p=0.06)$. However, older generation segments preferred red currants to wild cranberries, and they were also willing to pay more for a red currant dessert ( $p<0.05$ in all cases). In the grouping of assessors, the most significant differences appear in the popularity of the main courses. While the youngest generation segment statistically significantly prefers a pork dish $(p=0.02)$, wild boar meat is significantly more preferred by the other two older generation segments $(p=0.02$ and $p<0.01)$. However, paradoxically, no generation segment reflects preferences in WTP $(p=0.21$ to $p=0.88)$. 
Table 8. Results of sensory evaluation of acceptability and WTP in the grouping of assessors depending on the generation segment.

\begin{tabular}{|c|c|c|c|c|c|c|c|c|c|c|c|c|}
\hline \multirow{2}{*}{ Eval. Dish ${ }^{1}$} & \multicolumn{6}{|c|}{ Sensory Evaluation of Acceptability } & \multicolumn{6}{|c|}{ WTP in CZK } \\
\hline & GYy ${ }^{1}$ & $p$-Value ${ }^{2}$ & GYo $^{1}$ & $p$-Value ${ }^{2}$ & $\mathrm{NM}^{1}$ & $p$-Value ${ }^{2}$ & GYy ${ }^{1}$ & $p$-Value ${ }^{2}$ & GYo $^{1}$ & $p$-Value ${ }^{2}$ & $\mathrm{NM}^{1}$ & $p$-Value ${ }^{2}$ \\
\hline $\mathrm{C} 1$ & $5.49 \pm 2.44$ & \multirow[b]{2}{*}{0.14} & $5.31 \pm 2.18$ & \multirow[b]{2}{*}{0.38} & $6.32 \pm 1.96$ & \multirow[b]{2}{*}{0.16} & $57.56 \pm 15.78$ & \multirow[b]{2}{*}{$0.01 *$} & $51.88 \pm 17.21$ & \multirow[b]{2}{*}{0.44} & $51.36 \pm 17.26$ & \multirow[b]{2}{*}{0.82} \\
\hline W1 & $5.12 \pm 2.34$ & & $4.94 \pm 2.14$ & & $5.77 \pm 1.74$ & & $51.46 \pm 14.59$ & & $51.25 \pm 19.62$ & & $50.91 \pm 17.43$ & \\
\hline W2 & $6.22 \pm 2.02$ & $0.02 *$ & $6.94 \pm 1.29$ & $0.02 *$ & $7.05 \pm 1.59$ & $0.00 *$ & $151.95 \pm 31.30$ & 0.88 & $156.25 \pm 27.66$ & 0.53 & $155.91 \pm 25.85$ & 0.21 \\
\hline $\mathrm{C} 3$ & $7.02 \pm 1.42$ & \multirow{2}{*}{0.14} & $6.31 \pm 1.74$ & \multirow{2}{*}{$0.01 *$} & $6.54 \pm 2.13$ & \multirow{2}{*}{$0.05 *$} & $73.66 \pm 22.45$ & \multirow[b]{2}{*}{0.06} & $69.38 \pm 19.14$ & \multirow[b]{2}{*}{$0.05^{*}$} & $60.45 \pm 16.76$ & \multirow[b]{2}{*}{$0.04 *$} \\
\hline W3 & $6.71 \pm 1.78$ & & $5.13 \pm 1.50$ & & $6.00 \pm 2.29$ & & $69.51 \pm 23.12$ & & $61.88 \pm 15.15$ & & $56.82 \pm 18.87$ & \\
\hline
\end{tabular}

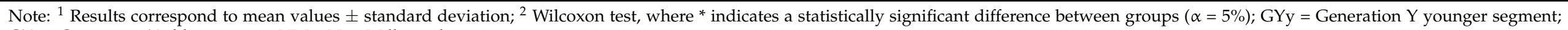
GYo = Generation Y older segment; NM = Non-Millennials 


\subsection{The Results of a Qualitative Research Survey Using Focus Groups}

The eight focus groups' results revealed fundamental causes of assessors' attitudes concerning the possible substitution of wild boar and pork meat. Below are listed frequently repeated statements if the assessors gave a higher evaluation to wild boar goulash. Individual agents are marked with the abbreviation A+No.:

"... the taste is somehow spicier, sharper, overall more interesting. Pork goulash bored me a little, classic, wild boar meat was ... deeper." (A37)

"The wild boar seemed more aromatic to me." (A18)

"I did not notice any significant difference. I liked both. If someone cooks for me, I eat anything, both were good." (A29)

"I would eat it even more often." (A5)

In the above case, the agents stated preferences for wild boar goulash, which they were able to substantiate with a rational justification for a specific flavor component. However, at the same time, an absolute indifference in the perception of wild boar and pork meat appeared in the statement. Another more general discussion, covering not just sensory aspects, implies several basic thematic categories: (1) concerns about alimentary disease and preliminary inspection of meat before serving, (2) unfamiliarity, nescience of appropriate game meat preparation, (3) condemnation of hunting, (4) unavailability in shops, (5) high price. The statements of the agents representing each of the above categories are listed below. Alternating statements of agents indicate group dynamics, as can be seen in Table 9:

Table 9. Selected statements of agents concerning the created thematic categories.

Thematic Category Number

(1)

(2)

(3)

(4), (5)
A Selected Statement Representing a Thematic Category (No. of Agent)

"Who knows what the boar ate in the woods, and then I should eat it? How can I be sure that the killed animal will really be inspected by an expert and not that the poacher will sell it straight to the pub? What if I catch some disease from that boar?" (A21)

"But when hunters shoot a wild boar, there are regulations, and the meat must be immediately inspected by a professional or handed over to a veterinarian for inspection. So, it is a safe way from hunters. Besides, the meat is not eaten raw, and heat processing will destroy any bacteria. I would not be afraid of that at all." (A23)

"The boar stinks, and I cannot imagine getting rid of that smell. I am not sure how I should prepare the boar; it seems more complicated than pork. It discourages me that the game must be marinated and left to rest before use, I prefer to have it in a restaurant, and I would not have work to do at home." (A2)

"For me, it is a terrible idea of an animal trying to run away in agony before death." (A77) "... for a pig from a factory farm that goes to the slaughter, it is much harder. Pigs somehow feel that they are going to the slaughterhouse and I think they are more stressed than the animal in the forest, which is shot by a hunter who usually hits the first time. The animal in the forest will die quickly. And the wild boars have to be shot anyway; they are overpopulated ..." (A74)

"I do not see much game meat in stores, and if I do, it costs more than chicken or pork." (A18)

"Yes, the game meat is more expensive, but the taste is just something else." (A69)

"For me, today's chickens are universal and tasteless; at least the boar is authentic.

Moreover, as far as I know, for hunters, the purchase price is low, the chains then add a

high margin. The game meat can be obtained cheaply from hunters; they now have a lot of it because they have to shoot all year round." (A49)

\section{Discussion}

The possibility and need for boar meat based on the culls' time-series analysis can be expected in the following periods, especially in Germany and the Czech Republic. The topicality of the researched issue concerning the use of wild boar meat can be substantiated 
mainly by its only marginal consumption by consumers [3-5], even though it is a rapidly growing animal species in European countries and the USA [14,16-18,21-24,29]. This trend is likely to continue to prevail in the future [30,32].

Our research complements several studies that have already examined the effect of substitution of different meat types on the dish's sensory characteristics [98-103]. However, compared to the previous ones, the substitution of meats in our study is at medium-level: there is no comparison of different types of treatments or meat from animals of the same breed or species, which would differ in the breeding system $[98,99]$. On the other hand, we do not compare meat from animals that came only from the same order or family $[100,101]$, but two meat species derived from different however closely related species: domesticated and wild (considered the domesticated species' ancestor).

Based on our study's sensory evaluation results, a specific way of using wild boar meat can then be implied, either at a general level or for individual segment consumers or customers and their potential purchasing behavior. Without consumers' grouping, wild boar meat, while maintaining the dish recipe's standardization, can be described as an appropriate partial substitute for pork, unlike other wild food ingredients. Therefore, it can be summarized that there is a possibility of using wild boar meat in gastronomy, without losing the dish's quality. It is consistent with previous studies [3,5] which show the high popularity of wild boar among various game species and the results of a study by Ježek [67], which gives wild boar and pork as substitutes from a sensory point of view.

These preferences were reflected in buyers' subsequent willingness to spend their money. Specifically, buyers who have tasted wild boar meat will spend the same amount of money on such a dish as on pork meat. Neither sellers of wild boar meat nor owners of gastronomic establishments have to sell wild boar meat or wild boar dishes cheaper than pork meat or pork dishes. They can choose at least prices at the same level. Wild boar meat in this respect significantly surpasses other wild food ingredients. However, wild boar dishes cannot be sold significantly more expensive than pork dishes.

Unlike other studies examining the effect of meat information presented to the buyer on his/her WTP during the purchase decision for wild game meat [40], our study has so far looked at little-studied WTP depending on sensory evaluation of the dish. Thus, the assessors themselves were not affected by any information during the blind tasting, and the benefit of our study is in providing purely preferential sensory results. Following our study results, we offer the creation of a follow-up working hypothesis, which would include examining the impact of sustainability practices information, specifically of wild boar meat and products on the consumers' WTP. This information would be presented to the buyer as well as in other studies [48]. Research that has used various attributes on meat and meat product labels such as "welfare", "organic", or "pasture-based" can serve as inspiration, and these attributes have significantly influenced consumers' WTP $[38,110]$

A more detailed analysis of our results indicated that different preferences and WTP for dishes containing wild food could not be found, for example, concerning income, education, or family situation (in contradiction with the study of Xazela et al. [47]). In contrast, the gender, the rural or urban origin (following Senthilkumar and Muralidhar [111]), and the consumer's age play a significant role. The wild boar meat showed the highest hedonic acceptance of all wild food ingredients even amongst men that refused other wildlife ingredients, as previously confirmed by Bureš and McAfee $[3,46]$. Such results can help sellers of wild boar meat or wild boar products. They can target their offer to specific consumer segments and adjust the price. Even for grouping by gender (males and females) and place of origin of consumers (urban and rural), a dish containing wild boar meat reports outstanding quality evaluation results comparable to a pork dish. Besides, sellers of wild boar meat and wild boar dishes can use the same price for their products as selling pork meat- to men, women, urban and rural consumers. The study's result is that rural and female consumers are even less demanding, as they also accept other wild food ingredients added to starters and desserts (no multicollinearity between groups appeared). 
Generation segments saturate the whole survey more as they bring the most significant discrepancies within individual generation segments. Consumers under the age of 24 were the only segment in the entire survey who strongly expressed their dislike of wild boar meat, yet without a willingness to pay more for pork meat. However, they accepted other wild food ingredients as positively as women or rural consumers did. Study in Norway by Kubberød et al. [112] with young people aged 16 to 17 years, 10 urban females, 10 rural females, and 10 rural males showed that disgust was solely related to red meat varieties and not chicken. Eating red meat was more common among males than females. Sensory attributes drivers of a liking for meat were good taste, good smell, and juiciness; both genders described this. Only women felt negative feelings towards body parts, blood and raw meat, greasy feeling in the mouth, and visible fat. Females also tended to associate meat with harming their bodies. For consumers aged 25 and more, the exact opposite result is essential about the study's focus, namely a more significant preference for wild boar meat over pork meat. Even here, however, their willingness to pay more for wild boar meat did not appear. Older consumers do not differentiate between other wild food ingredients for appetizers, but their preferences indicate a more demanding group of men and urban consumers for desserts. It can be stated that although the younger and older generations of consumers have their specific preferences regarding wild boar or pork meat, these preferences are not reflected in the willingness to pay more for their preferred choice.

The above-mentioned sensory results correspond well to the results of conducted focus groups, which revealed other wild boar meat problems, respectively, possible barriers perceived by consumers. The survey revealed that people are unaware of the possibilities of obtaining new game meat, often have prejudices about how wild animals are abused before death, reject the way of obtaining the game meat through hunting, which is distortedly perceived as a mere sports activity or killing for fun. Many previous studies confirmed these hunting concerns from the consumers' perspectives [38,51-56,59]. However, according to other studies [41,59-63], wild animals do not suffer from stress during the gentle hunting period, especially during the precise shot, and they are dead almost immediately. On the contrary, in domestic animals, a particular stress load cannot be avoided during transport to the slaughterhouse and subsequent slaughter, yet performed in compliance with strict regulations. Focus groups revealed that people usually do not know how wild animals meat is inspected after the hunt, and they are also concerned about a possible disease, which supports the conclusions of the other studies [41,51,113,114]. On the other hand, the conducted focus groups have not revealed dietary trend concerns connected with eating game meat previously highlighted by the other authors [42,43,51,67,72]. Although our research did not address future barriers to developing the game meat market, some authors have already explored this possibility.

Addressing food safety concerns, a mandatory labelling system for various types of meats is imposed. The development of a labelling program for hunted wild game meat products is expected to raise consumer awareness and knowledge about game meat and empower consumers to make informed purchasing decisions [113-117].

Based on the results of the conducted focus groups, we propose that food safety concerns connected with game meat could be significantly transformed by the systematic introduction, mediation, accessibility, and popularization of wild boar meat and game meat's nutritional values and health benefits. In this educational activity, forest pedagogy methods as a form of education for sustainable development can be used [118]. Forest pedagogy can contribute to raising awareness and increasing the consumption of wild boar meat, for example: (1) by emphasizing the nutritional value in favor of game meat; (2) by drawing attention to the fact that reducing the numbers of overpopulated wild animals will lead to the maintenance of balance in nature; (3) by tastings in places with a large number of people such as supermarkets, food festivals, and entertainment events with an accompanying forest-themed program; (4) by programs and competitions related to cooking transmitted by the media. Another important channel for sharing information is (5) children's education in schools with the irreplaceable role of teachers, forest educators, 
foresters, and hunters. Involving professionals into education is desirable and beneficial due to the differences between learning about versus learning from an expert $[119,120]$. The question of socialization is particularly severe in childhood [121]. Children are not passive recipients only. They are often the initiators of various new habits that they transmit to their siblings and parents. In this way, it is possible to create positive links between children and their parents to nature, the environment, and sustainable consumption behavior (including wild food) in the future.

This study's results are not intended to discourage consumers from buying pork meat, but to highlight there are at least partial substitutes for it, e.g., wild boar meat, that could be well accepted by consumers from the sensory perspective. Since overpopulated Sus scrofa could be at least partly considered as a substitute to the pork meat from large-scale farming (which is environmentally demanding as any other meat production $[1,2,9]$ we believe that this possible partial substitution is following sustainable principles relating to biological systems' ability to maintain diversity and productivity. More to this, The European Commission [122] recommended, among other things, changes in behavior to reduce the carbon emissions from food by eating local and seasonal food. Therefore, eating locally culled wild boar meat in countries dealing with their overpopulation is in line with a recommendation mentioned above. It could be a partial substitution for pork meat that is a significant part of international trade with meat, e.g., for the Czech Republic where our research was conducted, there were almost 69 tons of pork meat imported and 8,5 tons exported in 2020 [123]. Alfnes and Sharma [124] showed that consumers WTP for local meat is always higher. Additionally, the introduction of game meat into the diet means its diversification, as it has a lower fat content and higher protein content than pork; it is rich in proteins, iron, vitamin B12, and minerals [61,67,69,72-75].

Another contribution of our study is that there is no relevant paper that would examine in such detail the sensory evaluation in pair testing of heat-processed dishes prepared from wild boar and/or pork meat. Studies focused on either sensory attributes of wild boar $[125,126]$ or pork [92]. Additionally, the number of sensory assessors in our study $(\mathrm{n}=80)$ is approximately eight times higher than the number of professional evaluators, in research conducted by Bureš et al. [95] or Adam, Ata, Ismail [93]. This research' limitations relate to the use of only selected parts of the animal (leg, shoulder), the primary heat treatment (roasting, stewing) and the fact that only Czech consumers and Czech recipes were used.

In the future, the research can be extended to pork from different farms, differently fed individuals, or different carcasses of wild boar meat, or comparison of male and female boar meat, similar to studies in other animals [93]. Furthermore, wild boar can be compared with other game species such as in the study by Vigano et al. [94]. We recommend supplementing future research with a comparison of the results of the consumer and expert panels. A limitation that also controls standardization when comparing boar meat and pork meat in our research was the inclusion of meat in a sauce-goulash-which partially hides the color of meat, which is otherwise darker $[85,96]$. However, the inclusion of the sauce in our study allowed the color to be obscured, so consumers could compare meats as only very difficult to identify substitutes in terms of appearance.

Another limitation is connected with the acceptance of the premise that wild boar meat can be considered a sustainable source of nutrition which can be well substituted for pork. From a sensory point of view, it should be borne in mind that even the findings of our study do not necessarily mean a change in consumers' eating habits. As previous research by Oonincx et al. [127] has shown, sustainable food sources, such as various insect species (Pachnoda marginata, Tenebrio molitor, Blaptica dubia, Acheta domestica, and Locusta migratoria), which can produce significantly less $\mathrm{CO}_{2}$, e.g., in comparison with cattle or domestic pigs, do not mean an immediate turnaround in consumer preferences. It is one reason why we believe that the inclusion of qualitative research, e.g., focus groups, in which consumer attitudes can be detected in a broader social context, including the discovery of the causes of neophobia, is essential in studies dealing with sensory evaluation of 
food. In particular, encompassing of qualitative research could provide recommendations dealing with food consumer preferences driven by their eating habits, personal values, cultural identity, economic, and religious aspects. In the religious context, pork and boar meat can be described as sensitive, for example, to the Muslim community, who are willing to pay a premium for meat products in the Islamic butcher shop rather than in the supermarket [128]. In the future, food consumer preferences can be expected to be examined using a mixed-methods approach.

\section{Conclusions}

This research's results are relevant for policymakers and stakeholders involved in education, agriculture, hunting, and the food industry. They can utilize these proposals to design and develop successful strategies and appropriate communication tools to promote this new game meat market. The importance of this research is evident from the growing population of wild boars across European countries. This future trend directly implies the possibility of wild boar meat utilization obtained by blasting. Our study's results outlined the possibilities of culinary use of boar meat through sensory analysis of a little-used sensory panel, with relatively detailed segmentation of consumers, their sensory preference patterns, and their WTP. Our research's general results showed that wild boar meat has an excellent potential to replace pork meat within various generational segments (except consumers under 24 years).

However, in the vast majority of cases, there is no opportunity to surpass pork in quality, which could be why consumers are willing to pay neither more nor less for wild boar meat. Their indifferent perception of the quality of an ideal substitution for pork meat is probably why they expresstheir indifferent market behavior, including WTP. Such indifferent market behavior can be expected even for consumers older than 24 years, as the only segment of consumers that significantly prefers wild boar meat in the dish. These results can be perceived both positively and negatively depending on the point of view. On the one hand, boar meat quality cannot be highlighted above the quality of pork meat, and no more tremendous market potential for wild boar meat than pork meat can be expected. On the other hand, wild boar meat can be considered a partial substitute (or alteration) for pork meat, on which the seller can make the same profit as when using pork while maintaining the same costs.

Although the consumer evaluates the quality of meat based on its sensory properties, it is necessary to extend the comparable sensory results of pork and wild boar meat by another aspect related to consumer concerns arising from our focus groups. Concerns arising from low consumer awareness can be reduced through continuous education, such as through forest pedagogy, from an early age. Simultaneously, this approach can ensure the consumption of wild boar meat in the future, which can be considered sustainable and can also be considered a partial alternative to pig factory farming. As our survey results revealed, the added value of wild boar meat is that it increases the variety of diet and can represent a nutritional and enjoyment change from uniform factory production.

Author Contributions: Conceptualization, K.M.; J.Z. and Z.V.; Methodology, J.Z. and Z.V.; Validation, J.Z. and K.M.; Formal analysis, J.Z. and K.M.; Data curation, J.Z.; Writing-original draft preparation, K.M. and J.Z.; Writing—review and editing, K.M. and J.Z.; Supervision, J.Z.; Translation D.L.; All authors have read and agreed to the published version of the manuscript.

Funding: This research was carried out in connection with the research project of the Ministry of Culture of the Czech Republic No. DG18P02OVV067 entitled Culinary Heritage of the Czech Lands: Memory, Presentation and Education.

Institutional Review Board Statement: The study was conducted according to the guidelines of the Declaration of Helsinki, and approved by the Institutional Review Board of The Institute of Hospitality Management in Prague (protocol code HTV19-01 from 9 September 2019).

Informed Consent Statement: Informed consent was obtained from all subjects involved in the study. 
Data Availability Statement: The data presented in this study are available on request from the corresponding author. The data are not publicly available due to further evaluation within the research project of the Ministry of Culture of the Czech Republic No. DG18P02OVV067.

Acknowledgments: We would like to thank all 80 semi-trained assessors and anonymous reviewers for their valuable recommendations and comments, thanks to which this manuscript was continually being improved.

Conflicts of Interest: The authors declare no conflict of interest. The funders had no role in the study's design; in the collection, analyses, or interpretation of data; in the writing of the manuscript, or in the decision to publish the results.

\section{References}

1. Stuart, T. Waste: Uncovering the Global Food Scandal; Penguin Books: London, UK, 2009; ISBN 9780141036342.

2. Thøgersen, J. Country Differences in Sustainable Consumption: The Case of Organic Food. J. Macromark. 2010, 30, 171-185. [CrossRef]

3. Bureš, D.; Bartoň, L.; Kudrnáčová, E.; Panovská, Z.; Kouřimská, L. Maso divokých zvířat a jeho role v lidské výživě [Meat of wild animals and its role in human nutrition]. Výživa Potraviny 2018, 1, 9-13.

4. Shalbot, N.M.; McDermott, A.; Williams, C.; Payne, T.; Walters, D.; Yimin, X. The Key Element of Success and Failure in the NZ Venison Industry; Research report No. 312, 51; Lincoln University: Lincoln, New Zealand, 2008; ISBN 978-1-877519-01-7.

5. Panovská, Z.; Valentová, V.; Váchová, A.; Pokorný, J. Preference masa a masných výrobků u vysokoškoláků na konci dvacátého století [Preference of meat and meat products among university students at the end of the twentieth century]. Maso 2018, 19, 32-36.

6. Weizsäcker, E.U.; Wijkman, A. Come on!: Capitalism, Short-Termism, Population and the Destruction of the Planet; Springer: New York, NY, USA, 2018; ISBN 978-1-4939-7419-1.

7. Willett, W.; Rockström, J.; Loken, B.; Springmann, M.; Lang, T.; Vermeulen, S.; Murray, C.J.L. Food in the Anthropocene: The EAT-Lancet Commission on healthy diets from sustainable food systems. Lancet 2019, 393, 447-492. [CrossRef]

8. FAO. The State of Food and Agriculture Social Protection and Agriculture: Breaking the Cycle of Rural Poverty; Food and Agriculture Organisation of the United Nations: Rome, Italy, 2015; ISBN 978-92-5-108861-6.

9. Saxena, A.D. The Vegetarian Imperative; The John Hopkins University Press: Baltimore, MD, USA, 2011 ; ISBN 9781421402420.

10. Environmental Working Group Meat Eaters Guide Home Page. Available online: http://static.ewg.org/reports/2011 /meateaters/pdf/methodology_ewg_meat_eaters_guide_to_health_and_climate_2011.pdf (accessed on 13 January 2021).

11. Tang, K.L.; Caffrey, N.P.; Nóbrega, D.B.; Cork, S.C.; Ronksley, P.E.; Barkema, H.W.; Ghali, W.A. Restricting the use of antibiotics in food-producing animals and its associations with antibiotic resistance in food-producing animals and human beings: A systematic review and meta-analysis. Lancet Planet. Health 2017, 1, e316-e327. [CrossRef]

12. Valéry, L.; Fritz, H.; Lefeuvre, J.-C.; Simberloff, D. In search of a real definition of the biological invasion phenomenon itself. Biol. Invasions 2008, 10, 1345-1351. [CrossRef]

13. Mayer, J.J.; Brisbin, I.L. Wild Pigs: Biology, Damage, Control Techniques and Management; SRNL-RP-2009-00869; Savannah River National Laboratory: Aiken, SC, USA, 2009.

14. Barrios-Garcia, M.N.; Ballari, S.A. Impact of wild boar (Sus scrofa) in its introduced and native range: A review. Biol. Invasions 2012, 14, 2283-2300. [CrossRef]

15. Morelle, K.; Podgórski, T.; Prévot, C.; Keuling, O.; Lehaire, F.; Lejeune, P. Towards understanding wild boar Sus scrofa movement: A synthetic movement ecology approach. Mammal Rev. 2015, 45, 15-29. [CrossRef]

16. Morelllonio, M.; Andersen, R. European Ungulates and Their Management in the 21st Century; Cambridge University Press: Cambridge, UK, 2010; ISBN 9780521760614.

17. Fonseca, C. Distribution and numbers of the wild boar population in south eastern Poland. Pirineos 2002, 157, 39-46. [CrossRef]

18. Bueno, C.G.; Alados, C.L.; Gomez-Garcia, D.; Barrio, I.C.; Garcia-Gonzalez, R. Understanding the main factors in the extent and distribution of wild boar rooting on alpine grasslands. J. Zool. 2009, 279, 195-202. [CrossRef]

19. Podgórski, T.; Apollonio, M.; Keuling, O. Contact rates in wild boar populations: Implications for disease transmission. J. Wildl. Manag. 2018, 82, 1210-1218. [CrossRef]

20. Červený, J.; Burda, H.; Ježek, M.; Kušta, T.; Begall, S. Magnetic alignment in wild boars. In Proceedings of the 9th International Symposium on Wild Boar and Other Suids, Hannover, Germany, 2-6 September 2012; Keuling, O., Ed.; Institute for Terrestrial and Aquatic Wildlife Research, University of Veterinary Medicine: Hannover, Germany, 2012.

21. Tack, J. Wild Boar (Sus scrofa) Populations in Europe: A Scientific Review of Population Trends and Implications for Management; European Landowners' Organisation: Brussel, Belgium, 2018.

22. Náhlik, A.; Cahill, S.; Cellina, S.; Gál, J.; Jánoska, F.; Rosell, C.; Massei, G. Wild Boar Management in Europe: Knowledge and Practice. Ecol. Conserv. Manag. Wild Pigs Peccaries 2017, 339-353. [CrossRef]

23. Bevins, S.N.; Pedersen, K.; Lutman, M.W.; Gidlewski, T.; Deliberto, T.J. Consequences associated with the recent range expansion of nonnative feral swine. BioScience 2014, 64, 291-299. [CrossRef] 
24. Lewis, J.S.; Corn, J.L.; Mayer, J.J. Historical, current, and potential population size estimates of invasive wild pigs (Sus scrofa) in the United States. Biol. Invasions 2019, 21, 2373-2384. [CrossRef]

25. Corlatti, L.; Hackländer, K.; Frey-Roos, F. Ability of wildlife overpasses to provide connectivity and prevent genetic isolation. Conserv. Biol. 2009, 23, 548-556. [CrossRef]

26. Coppens, C.M.; De Boer, S.F.; Koolhaas, J.M. Coping styles and behavioural flexibility: Towards underlying mechanisms. Philos. Trans. R. Soc. B Biol. Sci. 2010, 365, 4021-4028. [CrossRef]

27. Snow, N.P.; Jarzyna, M.A.; VerCauteren, K.C. Interpreting and predicting the spread of invasive wild pigs. J. Appl. Ecol. 2017, 54, 2022-2032. [CrossRef]

28. Bieber, C.; Ruf, T. Population dynamics in wild boar Sus scrofa: Ecology, elasticity of growth rate and implications for the management of pulsed resource consumers. J. Appl. Ecol. 2005, 42, 1203-1213. [CrossRef]

29. Turek, K.; Friedlová, E.; Strejček, R.; Samec, P. The development of the wild boars abundance in the Czech Republic, and influence of wild boar on small game population. In Proceedings of the 12th International Symposium on Wild Boar and Other Suids, Lázně Bělohrad, Czech Republic, 4-7 September 2018.

30. Arnett, E.B.; Southwick, R. Economic and social benefits of hunting in North America. Int. J. Environ. Stud. 2015, 72, 734-745. [CrossRef]

31. Giacomelli, S.; Gibbert, M.; Viganò, R. Community empowerment for managing wild boar: A longitudinal case study of northern Italy. Ecol. Soc. 2018, 23. [CrossRef]

32. Babička, C.; Diviš, V. Současné Problémy v Chovu Černé Zvěře [Current Problems of Wild Boars]. Myslivost Home Page. Available online: https:/ / www.myslivost.cz/Casopis-Myslivost/Myslivost/2000/Unor---2000/Soucasne-problemy-v-chovu-cerne-zvere (accessed on 21 January 2020).

33. Dall, D. Managing Feral Pigs Across Australia. Outlooks Pest Manag. 2010, 21, 277-279. [CrossRef]

34. Massei, G.; Kindberg, J.; Licoppe, A.; Gačić, D.; Šprem, N.; Kamler, J.; Náhlik, A. Wild boar populations up, numbers of hunters down? A review of trends and implications for Europe. Pest Manag. Sci. 2015, 71, 492-500. [CrossRef]

35. White, P. Why Eating Local Venison is a Sustainable Choice. Permaculture Home Page. Available online: https://www. permaculture.co.uk/readers-solutions/why-eating-local-venison-sustainable-choice (accessed on 15 March 2020).

36. Tesařová, S.; Ježek, F.; Steinauserová, I.; Bořilová, G. Senzorické hodnocení zvěřiny v Evropě [Senzoric evaluation of game meat in Europe]. Maso 2016, 27, 19-25.

37. Pondělíček, J. Doporučená Opatření Pro Redukci Početních Stavu Prasete Divokého na Území České Republiky [Recommended Measures for Reducing the Number of Feral Pigs in the Czech Republic]; Ministerstvo zemědělství ČR: Praha, Czech Republic, 2005; ISBN 978-80-7434-423-7.

38. Demartini, E.; Vecchiato, D.; Tempesta, T.; Gaviglio, A.; Viganò, R. Consumer preferences for red deer meat: A discrete choice analysis considering attitudes towards wild game meat and hunting. Meat Sci. 2018, 146, 168-179. [CrossRef]

39. Giacomelli, S.; Gibbert, M. He likes playing the hero-I let her have fun shooting. Gender games in the Italian forest during the hunting season. J. Rural Stud. 2018, 62, 164-173. [CrossRef]

40. Marescotti, M.E.; Caputo, V.; Demartini, E.; Gaviglio, A. Discovering market segments for hunted wild game meat. Meat Sci. 2019, 149, 163-176. [CrossRef]

41. Hoffman, L.C.; Wiklund, E. Game and venison-Meat for the modern consumer. Meat Sci. 2006, 74, 197-208. [CrossRef]

42. McCarthy, M.; Henson, S. Perceived risk and risk reduction strategies in the choice of beef by Irish consumers. Food Qual. Prefer. 2005, 16, 435-445. [CrossRef]

43. Verbeke, W.; Van Oeckel, M.J.; Warnants, N.; Viaene, J.; Boucqué, C.V. Consumer perception, facts and possibilities to improve acceptability of health and sensory characteristics of pork. Meat Sci. 1999, 53, 77-99. [CrossRef]

44. Verbeke, W. Beliefs, attitude and behaviour towards fresh meat revisited after the Belgian dioxin crisis. Food Qual. Prefer. 2001, 12, 489-498. [CrossRef]

45. Výsledky Mysliveckého Hospodaření [Hunting Management Statistics]. Ústav pro Hospodářskou Úpravu Lesů Home Page. Available online: https: / www.uhul.cz (accessed on 7 March 2020).

46. McAfee, A.J.; McSorley, E.M.; Cuskelly, G.J.; Moss, B.W.; Wallace, J.M.W.; Bonham, M.P.; Fearon, A.M. Red meat consumption: An overview of the risks and benefits. Meat Sci. 2010, 84, 1-13. [CrossRef] [PubMed]

47. Xazela, N.; Hugo, A.; Marume, U.; Muchenje, V. Perceptions of Rural Consumers on the Aspects of Meat Quality and Health Implications Associated with Meat Consumption. Sustainability 2017, 9, 830. [CrossRef]

48. Bodnár, E.; Bodnár, K. Main traits of the wild boar meat in its marketing. Lucr. Ştiinţifice 2014, 16, 12-16.

49. Becker, T.; Benner, E.; Glitsch, K. Consumer perception of fresh meat quality in Germany. Br. Food J. 2000, 102, 246-266. [CrossRef]

50. Glitsch, K. Consumer perceptions of fresh meat quality: Cross-national comparison. Br. Food J. 2000, 102, 177-194. [CrossRef]

51. Bodnár, K.; Benák, A.; Skobrák, B. Analyses of consumer preferences and attitudes on hungarian game meat market: Preliminary report. Lucr. Ştiinţifice 2010, 53, 9-12.

52. Verbeke, W.A.J.; Viaene, J. Ethical challenges for livestock production: Meeting consumer concerns about meat safety and AnimalWelfare. J. Agric. Environ. Ethics 2000, 12, 141-151. [CrossRef]

53. Bennett, R.; Blaney, R. Social consensus, moral intensity and willingness to pay to address a farm animal welfare issue. J. Econ. Psychol. 2002, 23, 501-552. [CrossRef] 
54. Frewer, L.J.; Kole, A.; Van De Kroon, S.M.; De Lauwere, C. Consumers attitudes towards the development of animal-friendly husbandry systems. J. Agric. Environ. Ethics 2005, 18, 345-367. [CrossRef]

55. Mayfield, L.E.; Bennet, R.; Tranter, R.B.; Wooldridge, M.J. Consumption of welfare-friendly food products in Great Britain, Italy and Sweden, and how it may be influenced by consumer attitudes to, and behaviour towards, animal welfare attributes. Int. J. Sociol. Food Agric. 2007, 15, 59-73.

56. Napolitano, F.; Girolami, A.; Braghieri, A. Consumer liking and willingness to pay for high welfare animal-based products. Trends Food Sci. Technol. 2010, 21, 537-543. [CrossRef]

57. Toma, L.; Stott, A.W.; Revoredo-Giha, C.; Kupiec-Teahan, B. Consumers and animal welfare. A comparison between European Union countries. Appetite 2012, 58, 597-607. [CrossRef]

58. Vanhonacker, F.; Verbeke, W. Public and Consumer Policies for Higher Welfare Food Products: Challenges and Opportunities. J. Agric. Environ. Ethics 2013, 27, 153-171. [CrossRef]

59. Herényi, B. Marketing channels and food safety requirements for handling and placing meat from hunted wild game on the Hungarian market. Trends Game Meat Hyg. 2014, 241-250. [CrossRef]

60. Carlsson, F.; Frykblom, P.; Lagerkvist, C.J. Consumer willingness to pay for farm animal welfare: Mobile abattoirs versus transportation to slaughter. Eur. Rev. Agric. Econ. 2007, 34, 321-344. [CrossRef]

61. Ramanzin, M.; Amici, A.; Casoli, C.; Esposito, L.; Lupi, P.; Marsico, G.; Mattiello, S.; Olivieri, O.; Ponzetta, M.P.; Russo, C.; et al. Meat from wild ungulates: Ensuring quality and hygiene of an increasing resource. Ital. J. Anim. Sci. 2010, 9, 318-331.

62. Cockram, M.S.; Shaw, D.J.; Milne, E.; Bryce, R.; McClean, C.; Daniels, M.J. Comparison of effects of different methods of culling red deer (Cervus elaphus) by shooting on behavior and post mortem measurements of blood chemistry, muscle glycogen and carcase characteristics. Anim. Welf. 2011, 20, 211-224.

63. Viganò, R.; Demartini, E.; Riccardi, F.; Corradini, A.; Besozzi, M.; Lanfranchi, P.; Gaviglio, A. Quality parameters of hunted game meat: Sensory analysis and pH monitoring. Ital. J. Food Saf. 2019, 8, 7224. [CrossRef] [PubMed]

64. Varian, H.R. Microeconomic Analysis, 3rd ed.; Norton: New York, NY, USA, 1992; ISBN 978-0-393-95735-8.

65. Baltzer, K. Consumers' Willingness to pay for food quality-The case of eggs. Food Econ. Acta Agric. Scand. 2004, 1, 78-90. [CrossRef]

66. McMillin, K.W.; Hoffman, L.C. Improving the quality of meat from ratites. Improv. Sens. Nutr. Qual. Fresh Meat 2009, 418-446. [CrossRef]

67. Ježek, F. Zdravotně bezpečná zvěřina [Health-safe game]. Maso 2016, 27, 12-18.

68. European Food Composition Table Home Page. Available online: http://www.fao.org/infoods/infoods/tables-and-databases/ europe/en/ (accessed on 5 January 2021).

69. Żochowska-Kujawska, J.; Kotowicz, M.; Sobczak, M.; Lachowicz, K.; Wójcik, J. Age-related changes in the carcass composition and meat quality of fallow deer (DAMA DAMA L.). Meat Sci. 2019, 147, 37-43. [CrossRef]

70. Slowak, M. Ein Beitrag zur Wildbrethygiene von Reh-, Schwarz- und Damwild [A Contribution to the Game Hygiene of Roe Deer, Wild Boar and Fallow Deer]; Universität Wien: Vienna, Austria, 1986.

71. Steinhauser, L. Hygiena a Technologie Masa [Meat Hygiene and Technology]; LAST: Brno, Czech Republic, 1995; ISBN 80-9002260-4-4.

72. Radder, L.; Le Roux, R. Factors affecting food choice in relation to venison: A South African example. Meat Sci. 2005, 71, 583-589. [CrossRef]

73. Winkelmayer, R. Hygiena Zvěřiny-Přŕručka pro Mysliveckou Praxi [Game Hygiene-A Handbook for Hunting Practice]; Institut Ekologie Zvěře VFU: Brno, Czech Republic, 2005; ISBN 80-7305-523-6.

74. Ingr, I. Produkce a Zpracování Masa [Meat Production and Processing], 1st ed.; Mendel University: Brno, Czech Republic, 2003; ISBN 80-7157-719-7.

75. Hrabě, J.; Březina, P.; Valášek, P. Technologie Výroby Potravin Živočišného Piovodu [Technology of Food Production of Animal Origin], 1st ed.; Univerzita Tomáše Bati ve Zlíně: Zlín, Czech Republic, 2006; ISBN 80-7318-405-2.

76. Townsend, W.E.; Brown, W.L.; McCampbell, H.C.; Davis, C.E. Comparison of Chemical, Physical and Sensory Properties of Loins from Yorkshire, Crossbred and Wild Pigs1. J. Anim. Sci. 1978, 46, 646-650. [CrossRef]

77. Kasprzyk, A.; Stasiak, A.; Babicz, M. Meat quality and ultrastructure of muscle tissue from fatteners of Wild Boar, Pulawska and its crossbreed Pulawska $\times$ (Hamshire $\times$ Wild Boar). Arch. Anim. Breed. 2010, 53, 184-193. [CrossRef]

78. Lachowicz, K.; Zochowska, J.; Sobczak, M. Comparison of the texture and structure of selected muscles of piglets and wild boar junveniles. Pol. J. Food Nutr. Sci. 2004, 13, 75-79.

79. Roberts, D.D.; Acree, T.E. Simulation of Retronasal Aroma Using a Modified Headspace Technique: Investigating the Effects of Saliva, Temperature, Shearing, and Oil on Flavor Release. J. Agric. Food Chem. 1995, 43, 2179-2186. [CrossRef]

80. Neethling, J.; Hoffman, L.C.; Muller, M. Factors influencing the flavour of game meat: A review. Meat Sci. 2016, 113, 139-153. [CrossRef]

81. ISO 6658:2017. International Organization for Standardization Home Page. Available online: https://www.iso.org/standard/65 519.html (accessed on 25 January 2020).

82. Pokorný, J. Metody Senzorické Analýzy Potravin a Stanovení Senzorické Jakosti [Methods of Sensory Analysis of Food and Determination of Sensory Quality]; Ústav zemědělských a potravinářských informací: Praha, Czech Republic, 1993; ISBN 80-85120-34-8.

83. Pokorný, J.; Valentová, H.; Pudil, F. Sensorická Analýza Potravin: Laboratorní Cvičení [Sensory Analysis of Food: Laboratory Exercise]; VŠCHT: Praha, Czech Republic, 1999. 
84. Rødbotten, M.; Kubberød, E.; Lea, P.; Ueland, Ø. A sensory map of the meat universe. Sensory profile of meat from 15 species. Meat Sci. 2004, 68, 137-144. [CrossRef]

85. Skobrák, E.B.; Bodnár, K.; Jónás, E.M.; Gundel, J.; Jávor, A. The comparison analysis of the main chemical composition parameters of wild boar meat and pork. Anim. Sci. Biotechnol. 2011, 44, 105-112.

86. Peryam, D.R.; Pilgrim, F.J. Hedonic scale method of measuring food preferences. Food Technol. 1957, 11, 9-14.

87. Daskiewicz, T.; Janiszewski, P.; Wajda, S. Quality Characteristics of meat from wild red deer hinds and stags. J. Muscle Foods 2009, 20, 428-448. [CrossRef]

88. Bořilová, G.; Hulánková, R.; Svobodová, I.; Ježek, F.; Hutárová, Z.; Večeřek, V.; Steinhauserová, I. The effect of storage conditions on the hygiene and sensory status of wild boar meat. Meat Sci. 2016, 118, 71-77. [CrossRef] [PubMed]

89. Żochowska-Kujawska, J.; Lachowicz, K.; Sobczak, M. Effects of fibre type and kefir, wine lemon, and pineapple marinades on texture and sensory properties of wild boar and deer longissimus muscle. Meat Sci. 2012, 92, 675-680. [CrossRef] [PubMed]

90. Guzek, D.; Głąbska, D.; Plewa, P.; Kozań, K.; Pietras, J.; Plewa, R.; Wierzbicka, A. Wild boar meat sensory attributes contributing general meat quality. Bull. Vet. Inst. Pulawy 2013, 57, 357-363. [CrossRef]

91. Istrati, D.; Ciuciu, A.M.; Ionescu, A.; Vizireanu, C.; Dinică, R. Influence of spice and wine based marinades on bovine Biceps femoris muscle tenderness. Afr. J. Biotechnol. 2012, 79, 14461-14467. [CrossRef]

92. Font i Furnols, M.; Gispert, M.; Guerrero, L.; Velarde, A.; Tibau, J.; Soler, J.; Oliver, M.A. Consumers' sensory acceptability of pork from immunocastrated male pigs. Meat Sci. 2008, 80, 1013-1018. [CrossRef] [PubMed]

93. Adam, A.A.G.; Atta, M.; Ismail, S.H.A. Quality and Sensory Evaluation of Meat from Nilotic Male Kids Fed on Two Different Diets. J. Anim. Vet. Adv. 2010, 9, 2008-2012. [CrossRef]

94. Viganò, R.; Aprico, J.; Besozzi, M.; Formenti, N.; Trogu, T.; Donazzolo, C.; Lanfranchi, P. Evaluation of pH in game meat of red deer hunted in autumn in the Western Italian Alps. Game Meat Hygiene 2017, 17, 241-246. [CrossRef]

95. Bureš, D.; Bartoň, L.; Kotrba, R.; Hakl, J. Quality attributes and composition of meat from red deer (Cervus elaphus), fallow deer (Dama dama) and Aberdeen Angus and Holstein cattle (Bos taurus). J. Sci. Food Agric. 2014, 95, 2299-2306. [CrossRef]

96. Marchiori, A.F.; Felício, P.E. Quality of wild boar meat and commercial pork. Sci. Agric. 2003, 60, 1-5. [CrossRef]

97. Miao, Z.; Hongbing, X.; Guowang, L.; Chang Zhong, L.; Wang, R.; GangCai, W. Comparison of calcium, copper, iron and zinc concentrations in pork and wild boar meat. In Proceedings of the 2011 International Conference on New Technology of Agricultural, Zibo, China, 27-29 May 2011. [CrossRef]

98. Górska, E.; Nowicka, K.; Jaworska, D.; Przybylski, W.; Tambor, K. Relationship between sensory attributes and volatile compounds of polish dry-cured loin. Asian Australas. J. Anim. Sci. 2016, 30, 720-727. [CrossRef]

99. Chumngoen, W.; Tan, F. Relationships between Descriptive Sensory Attributes and Physicochemical Analysis of Broiler and Taiwan Native Chicken Breast Meat. Asianaustralas. J. Anim. Sci. 2015, 28, 1028-1037. [CrossRef] [PubMed]

100. Tolentino, G.S.; Estevinho, L.M.; Pascoal, A. Microbiological quality and sensory evaluation of new cured products obtained from sheep and goat meat. Anim. Prod. Sci. 2016, 57, 391-400. [CrossRef]

101. Teixeira, A.; Silva, S.; Guedes, C.; Rodrigues, S. Sheep and Goat Meat Processed Products Quality: A Review. Foods 2020, 9 , 960. [CrossRef]

102. Castellari, E.; Marette, S.; Moro, D.; Sckokai, P. The Impact of Information on Willingness to Pay and Quantity Choices for Meat and Meat Substitute. J. Agric. Food Ind. Organ. 2018, 17. [CrossRef]

103. Lawo, D.; Böhm, L.; Stevens, G. Researchgate Home Page. Available online: https://www.researchgate.net/publication/344376 995_Veganaizer_AIassisted_Ingredient_Substitution/link/5f6dd23ca6fdcc00863a80d8/ (accessed on 15 January 2021).

104. Zelený, J.; Bednárová, K. Reverse OsmosisWater-BasedBeverages as a Product Innovation in Gastronomic Facilities: Expert Panelists' Sensory Evaluation and Generation Y Consumers' Attitudes. Econ. Agro-Aliment. 2019, 21, 49-72. [CrossRef]

105. ISO 8589:1998. International Organization for Standardization Home Page. Available online: https://www.iso.org/standard/15 879.html (accessed on 25 January 2020).

106. ISO WD TS 5568. International Organization for Standardization Home Page. Available online: https://www.iso.org/standard/ 81367.html (accessed on 23 January 2020).

107. USD Průměrné Kurzy 2019 [Average Exchange Rates USD: CZK], Historie Kurzů Měn Home Page. Available online: https: //www.kurzy.cz/kurzy-men/historie/USD-americky-dolar/2019/ (accessed on 17 April 2020).

108. Morgan, D.L. Ohniskové Skupiny jako Metoda Kvalitativního Výzkumu [Focus Groups as Qualitative Research]; Albert: Boskovice, Czech Republic, 2001; ISBN 80-85834-77-4.

109. Zamazalová, M. Marketing II; C.H. Beck: Praha, Czech Republic, 2010; ISBN 978-80-7400-115-4.

110. Risius, A.; Hamm, U. The effect of information on beef husbandry systems on consumers' preferences and willingness to pay. Meat Sci. 2017, 124, 9-14. [CrossRef]

111. Senthilkumar, V.; Muralidhar, M. Factors Influencing Meat Buying Behaviour among Rural, Semi-Urban and Urban Households. Int. J. Sci. Res. 2016, 5, 317-318. [CrossRef]

112. Kubberød, E.; Ueland, Ø.; Tronstad, Å.; Risvik, E. Attitudes towards meat and meat-eating among adolescents in Norway: A qualitative study. Appetite 2002, 38, 53-62. [CrossRef] [PubMed]

113. Verbeke, W. The emerging role of traceability and information in demand-oriented livestock production. Outlook Agric. 2001, 30, 249-255. [CrossRef] 
114. Verbeke, W.; Ward, R. Consumer interest in information cues denoting quality, traceability and origin: An application of ordered probit models to beef labels. Food Qual. Prefer. 2006, 17, 453-467. [CrossRef]

115. Bernués, A.; Olaizola, A.; Corcoran, K. Extrinsic attributes of red meat as indicator of quality in Europe: An application for market segmentation. Food Qual. Prefer. 2003, 14, 265-276. [CrossRef]

116. Grunert, K.G. Food quality and safety: Consumer perception and demand. Eur. Rev. Agric. Econ. 2005, 32, 369-391. [CrossRef]

117. Henchion, M.; McCarthy, M.; Resconi, V.C.; Troy, W. Meat consumption: Trends and quality matters. Meat Sci. 2014, 98, 561-568. [CrossRef]

118. Cornell, J. Sharing Nature with Children, 2nd ed.; Dawn Publications: Nevada City, NE, USA, 1998; ISBN 1-883220-73-4.

119. Berliner, D.C. Learning about and learning from expert teachers. Int. J. Educ. Res. 2001, 35, 463-482. [CrossRef]

120. Guskey, T.R.; Yoon, K.S. What Works in Professional Development? Phi Delta Kappan 2009, 90, 495-500. [CrossRef]

121. Schiffman, L.G.; Kanuk, L.L. Shopping Behaviour, 1st ed.; Computer Press: Brno, Czech Republic, 2004; ISBN 80-251-0094-4.

122. Faber, J.; Schroten, A.; Bles, M.; Sevenster, M.; Markowska, A.; Smit, M.; Rohde, C.; Dütschke, E.; Köhler, J.; Gigli, M.; et al. Publications. Europa.eu Home Page. Available online: http:/ / publications.europa.eu/resource/cellar/d9f5683a-b330-47c4-beacd4d4f5dec681.0001.07/DOC_1 (accessed on 7 January 2021).

123. Czech Statistical Office Home Page. Available online: https://www.czso.cz/csu/czso/cri/zemedelstvi-3-ctvrtleti-2020 (accessed on 3 January 2021).

124. Alfnes, F.; Sharma, A. Locally produced food in restaurants: Are the customers willing to pay a premium and why? Int. J. Revenue Manag. 2010, 4, 238. [CrossRef]

125. Sales, J.; Kotrba, R. Meat from wild boar (Sus scrofa L.): A review. Meat Science 2013, 94, 187-201. [CrossRef] [PubMed]

126. Nute, G.R.; Whittington, F.M.; Warriss, P.D.; Wood, J.D. Sensory analysis of boar taint. Influence of skatole on abnormal odour and flavour ratings. In Proceedings of the European Association for Animal Production Working Group, Milton Keynes, UK, 27-29 September 1995.

127. Oonincx, D.G.A.B.; Van Itterbeeck, J.; Heetkamp, M.J.W.; Van den Brand, H.; Van Loon, J.J.A.; Van Huis, A. An Exploration on Greenhouse Gas and Ammonia Production by Insect Species Suitable for Animal or Human Consumption. PLoS ONE 2010, 5, e14445. [CrossRef] [PubMed]

128. Verbeke, W.; Rutsaert, P.; Bonne, K.; Vermeir, I. Credence quality coordination and consumers' willingness-to-pay for certified halal labelled meat. Meat Sci. 2013, 95, 790-797. [CrossRef] [PubMed] 